\author{
MARCIN HinTZ \\ Christian Theological Academy in Warsaw, Poland \\ (D) https://orcid.org/0000-0001-7663-1085
}

\title{
Synod as the Embodiment of the Church - the Evolution of Lutheran Understanding of Synodality
}

\begin{abstract}
The concept of the synod plays a special role in the Evangelical ecclesiology. In the 20th century, the synod was radically defined as "the personification of the Church." In the Evangelical tradition, however, there are equal Church management systems: episcopal, synodal-consistory, presbyterian (mainly in the Evangelical-Reformed denomination), and to a lesser extent congregational (especially observed in the so-called free Churches). Reformation theology understands the Church as a community of all saints, where the Gospel is preached purely and the sacraments are properly administered (Augsburg Confession - CA VII). The system of the Church does not belong to the so-called notae ecclesiae. An important theological doctrine of the Reformation is the teaching about the universal priesthood of all believers, which is the theological foundation of the idea of the synodal responsibility of the Church. In the 19th century synods concerned mainly clergy. In the 20th century, in the course of democratisation processes, most Evangelical Churches raised the importance of the synod in the overall management of the Church, and the Polish Lutheran Church introduced a provision into her law which stipulates that the synod is "the embodiment of the Church" and its supreme authority.
\end{abstract}

Keywords: Protestantism, synod, Luther, ecclesiology, Church Law

\section{Introductory remarks}

In the Protestant tradition, the idea of synodality plays a special role in the ecclesiology, however, it must be stated that this was not always the case. It should be also noted at the outset that the synod's empowerment 
as the highest authority in the Lutheran and Reformed Churches was a long process. The synodal system is not the only form of regulating the order of the Church's management, but the formula that Synod as a congregation of clergy and laypeople is the highest authority in the Church is differentia specifica of the Protestant tradition.

To begin with, we have to clarify that according to the English-language tradition, the notion of Protestantism describes not only Lutherans and Presbyterians (Reformed Protestants), but also a huge number of Christian denominations that appeared after the 16th century Reformation and it is one of three major forces in the entire Christianity. ${ }^{1}$ Protestantism spread in the 19th century throughout the world, while till the 18th century it was more a European than a global movement. The synodal form of the Church structure is not the only one in the Protestant World. During the first stage of the development of the German Reformation, the dukes and councils of the cities played a patron's role in the structure of the Church. ${ }^{2}$ In this article, I will use the term Evangelical as a description of Lutheran and Reformed tradition among other Protestant denominations. In the German context, this term described by a sequence: Reformation - evangelisch - Protestantismus. ${ }^{3}$

Furthermore, we have to underline that the synodal understanding of the Institution of the Church is not a direct heritage of 16th century Reformation. Although, the hierarchy of power is unknown to the Evangelical tradition, instead only the hierodiaconia, or service - ministerium exercised in various departments and degrees. For the Reformation tradition, however, it was not the structure but a spiritual dimension of the Church that was of paramount importance. For the Reformer, Doctor Martin Luther (1483-1546), the Church was primarily a tool of God in the process of giving grace to humankind. The church is a community of believers in Christ, a community constituted and guided by the Holy Spirit. ${ }^{4}$

For Luther, the distinction between the visible and invisible Church was fundamental. All of the confessional books of the Lutheran denominations published in 1580 as Liber Concordia (Book of Concord) clearly followed this concept. One of the most important records in the confes-

${ }^{1}$ Encyclopedia Britannica, https://www.britannica.com/topic/Protestantism (accessed 29.11.2018).

${ }^{2}$ H.-J. Aвromeit: “The Luther Effect: What was the aim of the Reformer and what was the result?" Gdański Rocznik Ewangelicki 9 (2017), p. 111.

${ }^{3}$ U.H.J. KÖRTNER: Ökumenische Kirchenkunde. Lehrwerk Evangelische Theologie (LETh), Band 9. Leipzig 2018, p. 155.

${ }^{4}$ R. LeonhardT: Grundinformation Dogmatik: Ein Lehr- und Arbeitsbuch für das Studium der Theologie. Stuttgart 2009, p. 365. 
sional books of Lutheranism that describes this meaning can be found in the 1530 Confessio Augustana (Augsburg Confession, hereafter: CA). It is the fourth document included in the Book of Concord, written by Philip Melanchthon (1497-1560). Article 7 thereof defines the Church and teaches that there is one holy Christian Church, and it is found wherever the Gospel is preached in its truth and purity and the sacraments are administered according to the Gospel. It means that CA VII describes only 2 possible notae ecclesiae. In the second part of the Article of Faith, we read: "Nor is it necessary that human traditions, that is, rites or ceremonies, instituted by men, should be everywhere alike. As Paul says: One faith, one Baptism, one God and Father of all, etc. (Eph. 4:5-6)." 5

In the text of Apologia Confessionis Augustanae - in English: The Defense of the Augsburg Confession (hereafter: ACA), which expands upon the text of CA and refutes the Roman Catholic text Confutatio (originally titled Responsio Confessionis Augustanae), written by the theological commission headed by Johann Eck (1486-1543) we may find a deeper theological arguments on ecclesiology. ACA VII-VIII clarifies the difference of forms in the Church of Christ:

But just as the dissimilar length of day and night does not injure the unity of the Church, so we believe that the true unity of the Church is not injured by dissimilar rites instituted by men; although it is pleasing to us that, for the sake of tranquility [unity and good order], universal rites be observed, just as also in the churches we willingly observe the order of the Mass, the Lord's Day, and other more eminent festival days. And with a very grateful mind, we embrace the profitable and ancient ordinances, especially since they contain a discipline by which it is profitable to educate and train the people and those who are ignorant. ${ }^{6}$

Thus, denominational books of Lutheranism do not directly specify the organisation of the Church, that is, the Body of Christ.

Lutheranism in the times of Reformation did not introduce directly a new order or one model of the structure of the Church. Even Protestant theologians have a lot of difficulties while deciding on how to account for the political consequences of the teaching about Christian freedom. ${ }^{7}$ The synodal idea is a long-term ramification of the evolution of the Protestant ecclesiology.

${ }_{5}^{5}$ The Augsburg Confession - CA, Article VII, http://bookofconcord.org/augsburg -confession.php (accessed 20.03.2019).

6 ACA VII-VIII, 33.

${ }^{7}$ H. Assel: "Evangelische Freiheit als Erbe - heute" Gdański Rocznik Ewangelicki 6 (2012), p. 151. 


\section{Definition of synod}

The word synod comes from Greek sýnodos and means 'a meeting' as well as 'the conjunction of heavenly bodies'; in the Christian context, it acquired the meaning of a church congregation. From the middle of the 4 th century $\mathrm{AD}$, the term was used to describe the gathering of representatives of clergy and laity from a given diocese (this is a diocesan synod), metropolis (referred to as a provincial synod) or a country, that is, a plenary synod. In the Orthodox tradition, it is a permanent council of bishops acting as a superior body under the leadership of the head of a given Church bearing the dignity of a metropolitan or patriarch. In Protestant churches, the process of theological reflection on the role of the synod was a multi-stage one.

Today's definition says that the synod is a congress of representatives of the clergy and laity under the leadership of a superintendent or bishop, being the supreme authority of the Church in a given country or region. ${ }^{8}$ That is what the encyclopedic, general definition included in the multivolume Polish encyclopedia Religia. PWN Encyclopedia from 2003 says.

When applied to the Evangelical Churches, this definition is largely untrue, because in most of the Churches currently active, the position of the president of the synod is separated from the position of the bishop, which is an expression of the acceptance of the structures of the division of power. The bishop, being the president of the Consistory, represents the executive and judiciary body, while the synod is a mixed structure, a legislative power of a democratic nature.

In Luther's teaching about the Church, the theological basis for the common responsibility of the Church by clergy and laity is well-founded in the idea of the universal priesthood, known better as priesthood of all believers. The notion "priesthood of all believers" is not directly present in Luther's programme script from 1520 To the Christian Nobility of the German nation about the improvement of the Christian state. We will find therein a teaching in which he claims that all baptised Christians are priests and are spiritual in the eyes of God:

That the pope or bishop anoints, makes tonsures, ordains, consecrates, or dresses differently from the laity, may make a hypocrite or an idolatrous oil-painted icon, but it in no way makes a Christian or spiritual human being. In fact, we are all consecrated priests through Baptism, as St. Peter in 1 Peter 2:9 says, "You are a royal priesthood and a

\footnotetext{
${ }^{8}$ Entry: "Religia." In Encyklopedia PWN, Vol. 9, Warszawa 2003.
} 
priestly kingdom,” and Revelation 5:10, “Through your blood you have made us into priests and kings." 9

In another of the three programme scripts from 1520, that is, On the Babylonian Captivity of the Church, Luther clarifies this understanding of the Church ministry:

How then if they are forced to admit that we are all equally priests, as many of us are baptised, and thereby we truly are; why is the Ministry (ministerium) entrusted only to them and we consent to it (nostro consensu)? If they recognise this they would know that they have no right to exercise power over us (ius imperii, in what has not been entrusted to them) except insofar as we may have granted it to them, for thus it says in 1 Peter 2, "You are a chosen race, a royal priesthood, a priestly kingdom." In this way, we are all priests, as many of us are Christians. There are indeed priests whom we call ministers. They are chosen from among us, and who do everything in our name. That is a priesthood which is nothing else than the Ministry. ${ }^{10}$

These two very famous quotations and many other passages from Weimarana were for the generations of Lutherans that followed a source of the theological basis for the responsibility of the Church. In the Protestant understanding, the idea of Synod is found also in the Bible in the description of Act 15 - it is a unity of all Christians in the Body of Christ. ${ }^{11}$ The synodal thinking includes also the readiness to provide brotherly help as a sign of equality and brotherhood.

\section{Lutheran and Reformed understanding of the Church and her authority}

The restoration of the Western Church started by Martin Luther was originally intended to be a correction of the spiritual, moral, and organisational status of the ecclesial structure functioning in Western Europe at

${ }^{9}$ M. Luther: An den christlichen Adel deutscher Nation von des christlichen Standes Besserung [To the Christian nobility of the German nation about the improvement of the Christian state] (1520). WA 6, 407, 19-25.

${ }^{10}$ M. Luther: De captivitate Babylonica ecclesiae praeludium (1520), WA 6, 564, $6-11$.

${ }^{11}$ R. BÄUmLin: “Synode.” In: Religion in Geschichte und Gegenwart. Tübingen 1962, Bd. 6, p. 569. 
the beginning of the 16th century. The implementation of the project far exceeded the imagination of its creator. As noted by the Polish researcher of Luther, Manfred Uglorz, it is highly doubtful that Luther considered himself a man called to reform the Christian Church prior to the year 1517. ${ }^{12}$ Only external circumstances, that is, rejection of the postulates of reform by the Church's supreme authorities, the support of the university and brothers from the Augustinian order, the protectorate of the prince of Saxony and later the support of the city - all of this created an external framework for Luther, real opportunities for wider influence, which as a result of the interaction of several factors led to the creation of the third greatest confessional family within Christianity, Protestantism, over the course of about next fifty years.

During the Reformation, the idea of the Synod was introduced gradually. Reformers, originally assigned a leading role to the idea of the universal council, which was to lead to the reform of the entire Western Church. These ideas are expressed in the already mentioned Luther's programme text from 1520 To the Christian Nobility of the German nation about the improvement of the Christian state, ${ }^{13}$ which is an appeal to the emperor to convene a universal council and to present the idea of the universal priesthood of all the faithful (baptised), which underlies the synodal paradigm, as well as parish assemblies of local pastors. As a result of the parish visits carried out by Luther in 1528, the Reformation faction was in favour of subordinating the clergy to secular sovereignty (the so-called Landesherrliche Kirchenregiment).

Because of the impossibility of calling a general council, the Reformation faction set its own criteria for a future real council, ${ }^{14}$ which then forms the basis of later synodal ideas of Lutheranism. One of the basic criteria is the sola scriptura principle, requiring the synod to act in accordance with the provisions of the Holy Scriptures and prohibiting the formulation of new faith principles by the synod. Synods and councils are required to respect the provisions of secular authority and act within the existing law. Synods and councils of ancient Christianity should be a model for Evangelical synods.

In Confessio Augustana can we find not only definitions, but also a deeper description of the Church structure. This most important identity book for the Lutherans further ponders the organisational matters:

12 M. Uglonz: Marcin Luter. Ojciec Reformacji. Bielsko-Biała 2006, p. 44.

${ }_{13}$ M. Luther: To the Christian Nobility of the German nation about the improvement of the Christian state, WA 6, pp. 404-469.

${ }^{14}$ IDEM: Von Konziliis und Kirchen (1539), WA 50, pp. 509-653. 
Of Usages in the Church they teach that those ought to be observed which may be observed without sin, and which are profitable unto tranquility and good order in the Church, as particular holy days, festivals, and the like. Nevertheless, concerning such things men are admonished that consciences are not to be burdened, as though such observance was necessary to salvation. They are admonished also that human traditions instituted to propitiate God, to merit grace, and to make satisfaction for sins, are opposed to the Gospel and the doctrine of faith. Wherefore vows and traditions concerning meats and days, etc., instituted to merit grace and to make satisfaction for sins, are useless and contrary to the Gospel. ${ }^{15}$

CA XXVIII does not directly mention the only form of the Church's system and organisation, instead, it touches upon the scope of episcopal ministry:

There has been great controversy concerning the Power of Bishops, in which some have awkwardly confounded the power of the Church and the power of the sword. And from this confusion very great wars and tumults have resulted, while the Pontiffs, emboldened by the power of the Keys, not only have instituted new services and burdened consciences with reservation of cases and ruthless excommunications but have also undertaken to transfer the kingdoms of this world. ${ }^{16}$

It should also be emphasised that in CA there is almost nothing about synods, the word occurs once, in CA XIII, where the issue of the abolition of celibacy is discussed. The authors quote the decisions: "And so harsh was the dealing in the matter that not only were marriages forbidden for the future, but also existing marriages were torn asunder, contrary to all laws, divine and human, contrary even to the Canons themselves, made not only by the Popes but by most celebrated Synods." The synod is a representation of the Church community, not an extension of the apostolic college. These ideas emphasise the theological egalitarianism of Protestantism based on the idea of universal priesthood of all believers.

For the Swiss Reformers, Huldrych Zwingli (1484-1531) and John Calvin (1509-1564), in harmony with the teaching of the ancient Church, the synod has authority as far as their actions prove to confess the decision of the present Holy Spirit (Acts 15,28). ${ }^{17}$ Thus, it means that in the Evangelical-Reformed tradition, the idea of synodic church management was formulated in official form earlier than by Lutherans.

${ }^{15}$ CA XV Of Ecclesiastical Usages.

${ }^{16}$ CA XXVIII Of Ecclesiastical Power.

17 R. BäUmlin: “Synode”..., p. 670. 
During the First Zurich Dispute in 1523, Zwingli proposed the order of synodality for Church in Zurich in reference to the ancient concept of the provincial council which was adopted for the local Church. The developed form of church management in the Calvinist tradition was formulated by John Calvin in the 1561 Church Order of Geneva, under which four church offices were introduced in Geneva and then in the Evangelical-Reformed Churches: pastor, doctor, the elder (priest), and deacon. Together, they form a presbytery, or congregation (parish) council, which elects its representatives to the synod, understood not as the authority or assembly of the entire church people, but as a representative congress of all offices operating in the Church.

The Paris Synod of 1559, which implemented Calvin's theological and legal ideas, also had a great impact on the development of the reformed ecclesiology. French Confessio Gallicana and the so-called Huguenot Church Order (Discipline ecclesiastique) introduced a three-stage system of synods: regional, provincial, and general. ${ }^{18}$ This system was gradually adopted by other European Churches of the Reformed tradition (the Netherlands: 1566 Confessio Belgica; Scotland: 1560 Confessio Scotica, which had a powerful impact on the formation of the synodal-presbyterial system of most Reformed Churches in North America). The Reformed tradition strongly emphasises the independence of the Church and spiritual authority from the secular. The Synod in Dordrecht (1618-1619), which strengthened Calvinist science of predestination against the Armenians, was particularly important in the development of the Reformed doctrine.

In the Polish context, the first synodal structure was introduced by Protestant under the danger of the Counter-Reformation. The first form was provincial synod and later so-called General Synod of three Protestant Churches in Poland: Lutherans, Reformed, and Czech Brethren. ${ }^{19}$ The latest General Synod took part in Torun in 1595, which passed the law called Conclusiones Synodi Generalis Toruniensis. ${ }^{20}$

The period of the 17th and the 18th centuries in the Lutheran theology generally did not bring any new ideas or movements into the understanding of Church-Law relation as well into the organisation of the Church structure. ${ }^{21}$

${ }^{18}$ E. E. CARnIs: Christianity through the Centuries. A history of the Christian Church. Grand Rapid, Mich. 1981, p. 329.

${ }^{19}$ M. Hintz, M. HucaŁ: Wielowymiarowość ewangelickiego prawa kościelnego. Analiza porównawcza i teologiczno-prawna. Warszawa 2018, p. 50.

${ }^{20}$ Ibidem, p. 52.

${ }^{21}$ M. HucaŁ: "Idea państwa świeckiego w protestantyzmie od połowy XVII do XX wieku." Studia z Prawa Wyznaniowego 19 (2016), p. 176. 
The creation of the Evangelical-Union Church, a forced union of Lutherans and Calvinists in the Prussian state in the year 1817, whose church order introduced under the influence of Friedrich D.E. Schleiermacher's (1768-1834) idea contained "democratic tendencies" in the management of the Church, including presbytery-synod Church structure. ${ }^{22}$ Schleiermacher became the first President of the Prussian General Synod, who did not hold any leadership role in the Church. This change faced strong resistance from the local secular rulers, which led to the postponement of the introduction of the idea of synodality until the end of the 19 th century.

In the 20th century, in most Evangelical Churches, a synod is understood as the supreme legislative authority of the Church that chooses its spiritual superiors. In the Lutheran Churches established already in the 18th century in the United States, the idea of "ethnic synods" appeared, and individual local communities joined together in the so-called synods or state Churches. The process of merging individual "synods" into one American Lutheran Church concluded in 1988 with the creation of the Evangelical Lutheran Church in America (ELCA). The conservative Lutheran community in Missouri created its Church called the Lutheran Church Missouri Synod (LCMS).

\section{The Church structure - towards the empowerment of the Evangelical synod}

The management structure of a local Evangelical Church can, therefore, take the following forms: episcopalism, presbyterianism, and synodism..$^{23}$ Under no circumstances can papalism or caesaropapism be a form in the Evangelical ecclesiology, although mutations of the latter form have occurred in the history of the Evangelical Church. Congregationalism is characteristic ecclesial form of free Evangelical Churches, which is essentially formed as federation of independent base Churches. However, the Polish Pentecostal Church has a bishop's office.

The episcopal form of church organisation is characteristic of the Lutheran Nordic Churches, which emphasise the possession of personal apostolic succession. This is also a reference point for building an eccle-

${ }^{22}$ J. Wallmann: Kirchengeschichte Deutschlands seit der Reformation. Tübingen 2012, pp. 199-202.

${ }^{23}$ H. G. Pöhlmann: Abriß der Dogmatik. Gütersloh 1990, p. 323. 
sial community with the Anglican Church, that is, the Episcopal Church. In 1992, the Porvoo Community was established, that is, the union of thirteen European Churches of the Anglican and Lutheran traditions. ${ }^{24}$ The community's theological basis is Porvoo Common Statement, signed in Finland in 1992. A first Eucharistic service was celebrated in Porvoo, hence the name that became the name of this inter-Church organisation. The episcopal system, which emphasises the special role of the episcopal ministry, does not diminish the role of the synod in church management. Nowadays, the Poorvo Communion includes 15 member Churches.

The presbyterian system is essentially characteristic of the EvangelicalReformed tradition. The reformer of Geneva, John Calvin, as it has been already mentioned, separated four church offices, entrusting elders, that is, priests, with the management of the Church and supervision of church discipline.

In modern Lutheranism, the synodic system or synodic-consistory system of the Church is of particular importance, as is the case in the Polish Lutheran Church.

\section{Synod as the highest authority in the Legal Provisions of Polish Evangelical Lutheran Church}

The synodal system of church power, also called synodic-consistory system, along with episcopalism, is today the most well-known form of managing the Evangelical Lutheran Church. It is a sequence of the complicated long-drawn processes of democratisation of Protestant Churches in changeable political contexts. ${ }^{25}$ To further complicate the said system, it should be noted that many Lutheran Churches, apart from the following two authorities: the Consistory and the Synod, also have their own bishops' conferences, which usually oversee the purity of doctrine. As mentioned above, the Scandinavian or Nordic Protestant Churches, which emphasise the possession of personal apostolic succession, for understandable reasons position the episcopal office differently than the Churches of German provenance, where for many years the role of episcopal service was marginalised. This is clearly changing now, also as a result of theological reflection in the spirit of ecumenism.

${ }^{24}$ Porvoo Statement, http://porvoocommunion.org/porvoo_communion/statement/the -statement-in-english (accessed 12.11.2018).

${ }^{25}$ G. Pöhlmann: Abriß der Dogmatik. Gütersloh 1990, p. 324. 
In their activity, Evangelical Churches are guided primarily by the injunctions of the Holy Scriptures, and secondarily, by denominational Confessional Books, as well as other binding legal regulations and church documents. This paradigm is expressed in the reformative formula sola scriptura, which indicates the highest authority of the Scriptures in resolving all theological and ecclesial disputes. Depending on the confessional tradition, the role of symbolic books is greater, as in Lutheranism, or smaller, as is the case with the Reformed tradition.

The Polish Lutheran or Lutheran Church has a synodic-consistory system, the Evangelical-Reformed Church in the Republic of Poland defines its system as synodal-presbyterian. Polish Methodists belonging to the Evangelical-Methodist Church in fact belong to the world-wide structure which is the United Methodist Church (UMC), whose highest synodal body is the General Conference that meets every four years in the United States. The head of the Polish Methodists is the bishop based in Switzerland. Therefore, they accept as their own good the UMC's official moral principles and have the right, through their own synodal structure, which is the annual conference, to create their own statements following the spirit of the Social Creed of Methodism.

In the following analyses, I will refer primarily to the mainstream Polish Protestantism, which has been Lutheranism since the 18th century. As a matter of fact, it is the only Polish Evangelical Church with a broader social impact, although it composes a considerable percentage of the population in only two Silesian counties: Bielsko-Biała and Cieszyn.

The Polish Lutheran Church in the 16th and 17 th centuries did not codify her church law, regional and provincial synods were convened locally. Polish Calvinists adopted a synodic system similar to Swiss legal solutions. In the 19th century, the Tsarist authorities imposed a consistory system on the Evangelical Churches that had developed, which gradually evolved in Polish Lutheranism towards the concept of consistory and synodality, and in Polish Calvinism towards synodic-presbytery. In the Polish legal reality, the synod in the 19th and at the beginning of the 20th century functioned as a congress of pastors with a more or less formal course, the real authority in the Church belonged to consistory. ${ }^{26}$

Special role of the Synod in church regulations is enshrined only in the act of state law which was the Decree of the President of the Republic Poland of November 25, 1936 on the State's stance towards the Evangeli-

${ }^{26}$ J. KŁaczKow: Kościół Ewangelicko-Augsburski w Polsce w latach 1918-1939. Toruń 2017, p. 16. 
Marcin Hintz

cal Church of the Augsburg Confession in the Republic of Poland. ${ }^{27}$ Article 1(3) stated that:

The Basic Internal Law of the Evangelical Church of the Augsburg Confession in the Republic of Poland, together with the decree, creates the legal basis for the organisation of this Church.

While Article 17(1) thereof stated:

The Bishop of the Evangelical Church of the Augsburg Confession in the Republic of Poland exercises the spiritual direction of that Church. He represents the Evangelical Church of the Augsburg Confession in the Republic of Poland before the state authorities and towards other denominations and is elected for life. The Bishop is also the President of the Synod and the President of the Consistory for life.

The regulations of the Synod of the Evangelical Church of the Augsburg Confession in the Republic of Poland of December 16, 1937 supplement the quoted regulations. ${ }^{28}$ This Act in Article 18 (1) defined the function of the Synod:

The synod of the Evangelical Church of the Augsburg Confession in the Republic of Poland is the supreme authority appointed to enact internal church laws as well as to decide on general matters of the Church. The synod is also the highest appellate body in church matters in cases provided for by the Basic Internal Law. The composition and competence of the Synod are also determined by the Basic Internal Law of the Augsburg Evangelical Church.

In practice, the scope of this power was limited by its work cycle, at least once every three years, but did not limit the authority of bishop.

After the Second World War, for decades of "real socialism," the Synod of the Church could not many prerogatives. The Law of the Church was changed in 1951 and 1964 saw major changes. The collection? of the

27 Prezydent Rzeczypospolitej Polskiej: Dekret z dnia 25 listopada 1936 r. o stosunku Państwa do Kościoła Ewangelicko-Augsburskiego w Rzeczypospolitej Polskiej. Dz.U. z 1936 r. $\mathrm{Nr}$ 88, poz. 613. In: Ewangelickie Prawo Kościelne 1918-2018. Zbiór tekstów prawnych kościołów ewangelickich w Polsce. Eds. M. Hintz, M. HucaŁ. Warszawa 2018, pp. 360— 362.

${ }^{28}$ Regulamin obrad Synodu Kościoła Ewangelicko-Augsburskiego w Rzeczypospolitej Polskiej z dnia 16 grudnia 1937 r. Dz. Urz. KEA z 1938 r. Nr 1 poz. 2, 370ff. In: Ewangelickie Prawo Kościelne 1918-2018... 
main Church Law, orders and regulations were printed first in $1972 .{ }^{29}$ In the 1964 edition of Internal Church Law, for the first time in history, we could find the formula: "[...] the Synod is the embodiment of the Church and an exponent of all rights of this Church." 30 In fact, this record had a formal significance, because to make any decisions, the Church authorities needed the approval decision of the communist state administration. The political breakthrough of 1989 also led to major changes in the internal law of the Protestant Churches in Poland.

The reform of the internal law of the Evangelical Church of the Augsburg Confession in the Republic of Poland in 1991 also resulted in deepening the ecclesiological reflection. Ecclesiology has been reformulated to emphasise the role of the diocesan superior, who in the current Protestant nomenclature used the title of senior. The 1991 Internal Church Law introduced the office of the diocesan bishop and established diocesan synods in place of previous diocesan assemblies.

The position of the synod within the Church was redefined, giving the Synod new prerogative, precisely describing it as "the personification (embodiment) of the entire Church."31

Therein, in paragraph 55 we may find the overall description of the Synod:

1. The Synod of the Church is the supreme authority of the Church. It is the personification of the Church and the exponent of all the rights of the Church. 2. The Synod of the Church is called to enact all church laws, as well as to decide in all general matters of the Church, under this law, excluding matters of norms of faith. ${ }^{32}$

We can see that the first part of point 1 of paragraph 55 is added to the notation from 1964.

An important provision is found in paragraph 60:

The President of the Synod of the Church, who is also the chairman of the Synod Council, elects the Synod from among clergy and lay members. The president of the Synod of the Church cannot be the bishop of the church. 3. The Synod Council during the Synod session

${ }^{29}$ Zbiór przepisów prawnych Kościoła Ewangelicko-Augsburskiego w PRL. Warszawa 1972.

${ }^{30}$ Zasadnicze Prawo Wewnętrzne Kościoła Ewangelicko-Augsburskiego w PRL z dnia 26 kwietnia 1964 r., § 52. In: Ewangelickie Prawo Kościelne 1918-2018..., p. 486.

31 Zasadnicze Prawo Wewnętrzne Kościoła Ewangelicko-Augsburskiego w Rzeczypospolitej Polskiej z dnia 31 maja 1991 r. In: Ewangelickie Prawo Kościelne 1918-2018..., pp. $552 \mathrm{ff}$.

${ }^{32}$ Ibidem, p. 560. 
constitutes the presidium of the Synod, and between the sessions represents the Synod and performs the tasks specified in this law and commissioned to it by the Synod of the Church.

It is a major change compared to the Church Law form 1936.

According to the current internal law adopted in 1996, with further minor changes, the Synod of the Church is the body competent to make decisions about formulating a document or position on a specific matter. The Initial Declaration of this Regulation underlines that the sources of faith and signs are above the synod. The internal law currently in force defines the role of the Synod in $§ 58$ :

1. The synod of the Church is the supreme authority of the Church. It is the personification of the Church and the exponent of all the rights of the Church.

2. The synod of the Church is called to enact all church laws, as well as to settle all general matters of the Church, under this Law.

3. The right included in point 2 does not apply to changes in the norms set out in the Initial Declaration..$^{33}$

The synod, therefore, decides on all matters of the Church, except for the fundamental and doctrinal ones. The function of the synod is also to elect the leading bishop of the Church for the period of 10 years.

At this point, we have to underline that the local Lutheran Churches belong to the world community. In the case of the Lutheran and Reformed Churches, the national Church is autonomous and independent of any non-national spiritual and secular authority. ${ }^{34}$ We can indicate here a certain parallelism to the Orthodox term autocephaly. Despite their autonomy, the Lutheran churches feel a strong internal bond, they are associated on a global scale in the Lutheran World Federation, which formally has been existing only since 1947, although before the Second World War there was already a global organisation of Lutheran Churches bringing together churches from Europe and Northern America. The resolutions of the LWF are not normative for the life of the Lutheran Church in Poland or in any other country, to an extent comparable with its own documents. However, disobeying truths of faith in line with the Lutheran

${ }^{33}$ Zasadnicze Prawo Wewnętrzne Kościoła Ewangelicko-Augsburskiego w Rzeczypospolitej Polskiej z dnia 26 października 1996 r. z późn. zm. In: Ewangelickie Prawo Kościelne 1918-2018..., pp. 40-42.

34 Ustawa z dnia 13 maja 1994 r. o stosunku Państwa do Kościoła Ewangelicko-Augsburskiego $w$ Rzeczypospolitej Polskiej, Dz.U. 1994, Nr 73, poz. 323. The same regulation is present in the Regulation between the Polish State and the Evangelical-Reformed Church in Republic Poland. In: Ewangelickie Prawo Kościelne 1918_2018..., p. 18. 
tradition, and inappropriate social attitudes can result in the exclusion of the local Church from the LWF community. For the last time, such a burning issue within the global Lutheran community was the issue of racism, condoned by some Churches of southern Africa, which resulted in their removal from the LWF. Reaching consensus on a forum of a very pluralistic organisation, which is a global Federation, is a very difficult task. In recent years, however, the sense of belonging to the world community, that is, the global ecclesial structure, has increased in the member churches. It should be emphasised here that the ecumenical Joint Declaration on the Doctrine of Justification between the Roman Catholic Church and the Lutheran World Federation of 1999 is of great merit.

So we can say at this point that by proceeding during the Synod, and also by creating synod documents that have the rank of official statements of the Church, their creators face a very difficult task: compliance with the sola scriptura principle, reference to world discussion taking place on the LWF forum and attitude to legal, ethical, social, or simply political debate taking place in a given country. The synod is aware that it represents the whole Church and represents its personification and embodiment.

\section{Conclusions}

Our analysis shows the transformation of the understanding of the synod in the history of Protestantism and its theology. The special role of the synod in modern Lutheranism was pointed out. The synod understands itself as the supreme organ of the Church's legislative power, representing the entire communio sanctorum in the local dimension, and finally as the embodiment of the local Church, which is part of the universal Church of Christ, whose head and pastor is Jesus Christ himself.

\section{Bibliography}

Аввомеiт H.-J.: "The Luther Effect: What was the aim of the Reformer and what was the result?" Gdanski Rocznik Ewangelicki 11 (2017), pp. 107-114.

Assel H.: "Evangelische Freiheit als Erbe - heute." Gdański Rocznik Ewangelicki 6 (2012), pp. 149-162. 
Augsburg Confession. In: Book of Concord, http://bookofconcord.org/augsbur -gconfession.php (date of access: 20.03.2019).

Apologia Confessionis Augustanae. In: Book of Concord, http://bookofconcord. org/defense_greeting. (date of access: 20.03.2019).

Bäumlin R.: "Synode. " In: Religion in Geschichte und Gegenwart. Tübingen 1962, Bd. 6, pp. 569-571.

Carnis E. E., Christianity Through the Centuries. A history of the Christian Church. Michigan 1981.

Prezydent Rzeczypospolitej Polskiej: Dekret z dnia 25 listopada 1936 r. o stosunku Państwa do Kościoła Ewangelicko-Augsburskiego w Rzeczypospolitej Polskiej. Dz.U. z 1936 r. Nr 88, poz. 613.

Encyclopedia Britannica, https://www.britannica.com/topic/Protestantism (accessed: 29.11.2018).

Ewangelickie Prawo Kościelne 1918-2018. Zbiór tekstów prawnych kościołów ewangelickich w Polsce. Eds. M. Hintz, M. HucaŁ. Warszawa 2018.

Hintz M., Hucaє M.: Wielowymiarowość ewangelickiego prawa kościelnego. Analiza porównawcza i teologiczno-prawna. Warszawa 2018.

HucaŁ M.: "Idea państwa świeckiego w protestantyzmie od połowy XVII do XX wieku." Studia z Prawa Wyznaniowego 19 (2016), pp. 175-193.

KŁaczKow J.: Kościół Ewangelicko-Augsburski w Polsce w latach 1918-1939. Toruń 2017.

KÖRTner U. H. J.: Ökumenische Kirchenkunde. Leipzig 2018.

LEONHARDT R.: Grundinformation Dogmatik: Ein Lehr- und Arbeitsbuch für das Studium der Theologie. Stuttgart 2009.

Luther M.: An den christlichen Adel deutscher Nation von des christlichen Standes Besserung [To the Christian nobility of the German nation about the improvement of the Christian state] (1520), WA 6, pp. 404-469.

Luther M.: De captivitate Babylonica ecclesiae praeludium (1520). WA 6, pp. $497-573$.

Luther M.: Von Konziliis und Kirchen (1539). WA 50, pp. 509-653.

Pöhlmann H.G.: Abriß der Dogmatik. Ein Kompendium. Gütersloh 1990.

Porvoo Statement, http://porvoocommunion.org/porvoo_communion/statement /the-statement-in-english/ (date of access: 12.11.2018).

Prezydent Rzeczypospolitej Polskiej: Dekret z dnia 25 listopada 1936 r. o stosunku Państwa do Kościoła Ewangelicko-Augsburskiego w Rzeczypospolitej Polskiej. Dz.U. z 1936 r. Nr 88, poz. 613.

Regulamin obrad Synodu Kościoła Ewangelicko-Augsburskiego w Rzeczypospolitej Polskiej z dnia 16 grudnia 1937 r. Dz. Urz. KEA z 1938 r. Nr 1 poz. 2.

“Religia.” In: Encyklopedia PWN, Vol. 9, Warszawa 2003.

Uglonz M.: Marcin Luter. Ojciec Reformacji. Bielsko-Biała 2006.

Ustawa z dnia 13 maja 1994 r. o stosunku Państwa do Kościoła Ewangelicko-Augsburskiego w Rzeczypospolitej Polskiej. Dz.U. 1994, Nr 73, poz. 323.

Wallmann J.: Kirchengeschichte Deutschlands seit der Reformation. Tübingen 2012.

Zasadnicze Prawo Wewnętrzne Kościoła Ewangelicko-Augsburskiego w PRL z dnia 26 kwietnia $1964 r$. 
Zasadnicze Prawo Wewnętrzne Kościoła Ewangelicko-Augsburskiego w Rzeczypospolitej Polskiej z dnia 31 maja 1991 r.

Zasadnicze Prawo Wewnętrzne Kościoła Ewangelicko-Augsburskiego w Rzeczypospolitej Polskiej z dnia 26 października 1996 r. z późn. zm.

MARCIN HinTZ

Le Synode comme incarnation de l'Église l'évolution de la compréhension luthérienne de la synodalité

Résumé

Le concept de synode joue un rôle particulier dans l'ecclésiologie évangélique. Au $\mathrm{XX}^{\text {ème }}$ siècle, le synode a été défini de manière radicale comme «incarnation de l'Église». Dans la tradition évangélique, cependant, il existe des systèmes égaux de gestion de l'Église: épiscopal, synodal-consistoire, presbytérienne (principalement dans l'église évangélique réformée) et dans une moindre mesure congrégationaliste (surtout pratiqué dans les structures de l'église libre). La théologie de la Réforme comprend l'Église comme une communauté de saints, où l'Évangile est clairement prêché et les sacrements sont correctement administrés (la Confession d'Augsbourg - CA VII). Le système de l'Église n'appartient pas aux notae ecclesiae. Une doctrine théologique importante de la Réforme est celle du sacerdoce universel de tous les croyants, qui est le fondement théologique de l'idée de responsabilité synodale pour l'Église. Au XIX ème siècle, les synodes concernaient principalement le clergé. Au cours des processus démocratiques du XX $\mathrm{X}^{\mathrm{eme}}$ siècle, la plupart des Églises évangéliques ont souligné l’importance du synode dans la gestion globale de l'Église, et l'Église luthérienne polonaise a introduit une disposition dans sa loi, selon laquelle le synode est l'incarnation de l'Église et son autorité suprême.

Mots clés : protestantisme, synode, Luther, ecclésiologie, droit de l’Église

MARCIN HinTZ

\section{SSinodo in quanto incarnazione della Chiesa - l'evoluzione dell'accezione luterana della sinodalità}

\section{Sommario}

Il concetto di sinodo svolge un ruolo speciale nell'ecclesiologia evangelica. Nel XX secolo, il sinodo è stato definito in modo radicale come "personificazione della Chiesa". Nella tradizione evangelica, tuttavia, ci sono sistemi equiparati di gestione della Chiesa: episcopale, sinodale-concistoro, presbiteriano (principalmente nella Chiesa evangelica riformata) e, in misura minore, congregazionalista (praticato soprattutto nelle strutture della chiesa libera). La teologia della Riforma intende la Chiesa come una comunità di santi in cui il Vangelo è chiaramente predicato e i sacramenti sono amministrati correttamente (Confessione di Augsburgo - CA VII). Il sistema della Chiesa non appar- 
tiene alle cosiddette notae ecclesiae. Un'importante dottrina teologica della Riforma è la dottrina del sacerdozio universale di tutti i credenti, che è il fondamento teologico dell'idea di responsabilità sinodale per la Chiesa. Nel XIX secolo, i sinodi riguardavano principalmente il clero. Nel corso dei processi democratici nel XX secolo, la maggior parte delle chiese evangeliche ha sollevato l'importanza del sinodo nella gestione generale della Chiesa, e la Chiesa luterana polacca ha introdotto una disposizione nella sua legge secondo cui il sinodo è l'incarnazione della Chiesa e la sua autorità suprema.

Parole chiave: protestantesimo, sinodo, Lutero, ecclesiologia, diritto della Chiesa 